\title{
Scientists and scientific associations in Catalonia (Spain) in the early 20th century: manuscript vs. published research in earth sciences
}

\author{
Josep Batlló \\ CGUL-IDL, Universidade de Lisboa, Portugal
}

\begin{abstract}
Culture in Catalonia and, specifically, science had an important rebirth in the second half of the 19th century. But, due to the lack of State support, development of earth physical sciences in Catalonia at the beginning of the 20th century was almost a private enterprise. This situation caused dispersion of the efforts that, in any case, were extensive. The study of the evolution of earth sciences and the recovery and study of the accumulated data in such circumstances requires relying heavily on manuscript information. The present study deals with the problems and possibilities of this situation, shows some study cases and extracts some conclusions of general interest from them.
\end{abstract}

Key words archives - Catalonia - scientific societies - Eduard Fontserè

\section{Introduction}

With the rising of European nationalisms in the 19th century, Catalonia and the Catalan culture flourished in the second half of that century. In fact, Barcelona, the capital of Catalonia, was, at the end of the 19th century, the cultural capital of the whole of Spain. This situation also implied a rebirth of the sciences as part of the cultural movement as a whole. Nevertheless, Barcelona was not the capital of Spain, a country with a highly centralised bureaucracy at that time, a faithful copy of French centralism. This situation imposed severe handicaps

Mailing address: Dr. Josep Batlló, CGUL-IDL, Universidade de Lisboa, Campo Grande, Edifício C8, 1749 016 Lisboa, Portugal; e-mail: jobatllo@fc.ul.pt. on some of the cultural initiatives that needed the support of the Spanish administration for their development. In general terms, individual authors or groups that did not needed large infrastructures were not really affected by this situation; but cultural fields that needed those larger organizations or equipment, among them the large laboratories needed by the applied sciences, suffered. On the same line, earth sciences, needing networks covering the territory, were not an exception and were handicapped by this situation.

Certainly, these situations were sometimes overrun by the initiatives of civil society and the resources of a powerful local bourgeoisie. In the scientific field, this situation gave rise to some private scientific initiatives and scientific societies that developed specific projects and took responsibilities larger than usually expected for such kind of enterprises. This special situation was, of course, not unique to Barcelona and Catalonia, affecting other cities and countries in Europe. In fact, it is one of the centrality-peripheries facets, but it has not been deeply 
studied up to now. Nevertheless, a study of what has been performed in these situations, mainly through investigating the preserved archives of such private institutions involved, is due because it enlightens some not well known contributions to science. In our case, the physical earth sciences and Catalonia, this paper analyse some study cases to show the new possibilities that such kind of research may offer for our present knowledge.

\section{Physical earth sciences in Catalonia at the turn of the 20th century}

First, to gain some insight on the problem to analyze, let us take a view to the main Catalan scientific institutions at their turn of the 20th century and the implication on the study of the physical earth sciences.

- The University of Barcelona. Spanish universities at that time were not research centres. This was a State supported institution but research was not among its objectives and only few professors did some research on their own. Still anchored in the scholastic doctrines, its main task was the teaching of courses. Among them, some notions on meteorology and earth sciences were taught in the physics courses. Also, the university housed the official meteorological observatory of Barcelona from 1861.

- The academy of medicine. At the end of the 19th century, medical research, following the hygienist doctrines, was deeply interested in the influence of climate on human health. For this reason, some physicians were deeply interested in meteorology. Furthermore, Catalan physicians were very active as animators of the cultural movement and activities (Pardo and Martínez, 2003). The archives of the academy still keep many medical topographies with interesting meteorological studies for several towns in Catalonia. Among them, the oldest regular daily series of meteorological observations for Barcelona, that was started by F. Salvà in the 18th century (Barriendos, 2005 and references therein). The main problem for such studies from our present point of view is the lack of coordination and general objectives. No support was received from the State for any of the organized activities.
- Academy of Sciences and Arts of Barcelona. This private institution was, since its foundation in 1764 and for many years, the most important science centre in Barcelona. Among their sections, there were, at the turn of the 20th century two commissions, one on exogenous and one on endogenous meteorology (a clear influence of the Italian thinking on earth sciences) related to our field of interest. From 1883 there were projects to install an observatory with meteorological and geophysical sections and even a meteorological network covering the whole of Catalonia (Roca, 2000) was devised, but nothing was really done after a few years.

- School and Experimental Farm of Barcelona. At that time, agricultural studies in Spain were organised around special «farm schools» offering different levels of qualification, depending on the school, and located in different towns. The Barcelona school was an important one. Also, at that time, the study of meteorology was considered an important topic for the students of agriculture. This is the reason the director of the school, H. Gorria (18431920), who had a special interest in this matter, installed a complete meteorological station in 1894 and one year later, managed to organise the first meteorological network in Catalonia. This network relied on the voluntary collaboration of the different observers and came to fill the absence of a State network. But this voluntarism was also the reason because, after the initial promising results and hesitation, around 1905 it was almost defeated. Nevertheless, it represents one of the first examples of self-organisation of the Catalan society to supply some deficits of the State administration in the scientific field. In this case, it was the absence of a meteorological network.

The early years of the 20th century saw a growth of new initiatives, some of them undertaken by the existing organizations and others by new founded groups. Among them, the most significant (but not unique) for the development of the physical earth sciences were:

- Fabra Observatory. The Academy of Sciences, at the turn of the 20th century, received a grant that allowed it to realize, at last, the long desired project of an Observatory. It received 
the name of Fabra Observatory. Located in the neighbourhood of Barcelona, it was inaugurated in 1904 and was organised in three sections: astronomy, meteorology and seismology.

- Ebre Observatory. This observatory was created by the Jesus Society and it was also inaugurated in 1904. It was a large observatory at that time and, from the first moment, had a wide international projection. It was mainly devoted to the study of Solar-Terrestrial Physics and there were meteorological and geophysical sections in it (Cirera, 1905). The origin of this observatory is not directly related to that of the other initiatives presented. It came from the interest of Jesuits to give a good scientific basis to their students (it was next to the philosophy school) and also from the specific interest to continue the research started by Catalan Jesuits at the Manila Observatory after the Spanish colonial regime in the Philippine islands ended in 1898 (see Batlló, 2002, or Saderra Masó, 1915 and references therein).

- Pluviometric network of Catalonia. R. Patxot (1872-1964) was a wealthy businessman deeply interested in many aspects of culture, among them, meteorology (for a biography, see Maluquer, 1994). He installed his own observatory (astronomical and meteorological) in Sant Feliu de Guíxols, a small town to the north of Barcelona. When the meteorological network of the Experimental Farm of Barcelona faded, he took over the task of collecting the pluviometric data of the meteorological stations of Catalonia. The results of this important effort were published in two books whose edition and printing were directly paid by Patxot himself (Patxot, 1908; 1912).

- Astronomical Society of Barcelona. It was an example of a scientific society like many others that flourished at that time in Europe. It was founded in 1911 and its main interest for our study is that this society (even called «astronomical») was the continuation of the meteorological network attached to the Experimental Farm and the pluviometric network of Patxot. In coordination with the Central Spanish Meteorological Office (this was the first time the Central Meteorological Office looked for this kind of collaboration in Spain), it managed a dense pluviometric network (more than 200 stations) in
Catalonia. The voluntary basis of its network was again its weakness and around 1920 it was defeated. Also, it is worth noting that this society elaborated for some time daily meteorological charts on a continuous daily basis.

- Astronomical Society of Spain and America. This society was also created in 1911 in Barcelona. It was born, in part, due to the division existing at that time among the Catalan astronomers and it represented the response of those that felt excluded from the Astronomical Society of Barcelona. This society was not so active in the earth sciences domain. Nevertheless, its president, J. Comas Solà (he was also in charge of the astronomical section of Fabra Observatory up to his death in 1937), operated a seismograph for several years in his private observatory in Barcelona (Batlló, 2004).

- Meteorological Survey of Catalonia (SMC). It was created in 1921. In this case, it was an official institution not dependent on the State Central administration but on the regional administration (after 1914, some administrative autonomy for Catalonia was gained and a regional government named «Mancomunitat de Catalunya» supported some initiatives). As can be seen from the previous paragraphs, meteorology was an extremely popular science in Catalonia. In this sense, this meteorological survey represented the fulfilment of so many years of voluntary work by so many observers, researchers and other private observatories not cited here.

In 1939, with the victory of fascist forces in Spain, this meteorological survey was eliminated and its archives directly seized by the victorious army. In 1984 they were returned and recently have been classified (Batlló, 2003). An important part of the documentation used for the present study comes from them.

As it can be seen, the absence of a solid State administrative structure caused a large dispersion of efforts in the physical earth sciences domain. There were many more initiatives not analysed here, especially in the meteorological field. For example, religious institutions managed many important meteorological observatories (Montserrat, Sabadell, Mataró, Sant Julià de Vilatorta, Les Avellanes, ...), and some amateurs installed astronomical observatories. Nevertheless, it is important to note that, 
in this special case of the physical earth sciences in Catalonia, there is a nexus between the principal cited initiatives giving some extra coherence to the different enterprises. This nexus relies just on one person, E. Fontserè (18701970). In a quick sketch, let us say that he was already in charge of the meteorological network of the Experimental Farm. Later, he was member of the Academy of Sciences and director of the meteorological and seismological section of the Fabra Observatory. At the same time, he was president of the Astronomical Society of Barcelona and, finally, he was the director of the Meteorological Survey of Catalonia (for a more detailed biography, see Iglesies, 1983, or Roca, 1995). If he had not been present in these places, it is quite possible that all the efforts would have become more and more dispersed. In fact, the Meteorological Survey acted during its existence as a cohesion force of the previous initiatives and was the depositary, among others, of the meteorological archives of the Experimental Farm and the whole archive of the Astronomical Society of Barcelona. It is noteworthy that Fontserè himself spoke and wrote many times about the «observational physical sciences», from his point of view a group of sciences including meteorology, seismology and astronomy where data were collected in the field. He put them together in opposition to other branches of physics where data were obtained through special experiences designed in a laboratory (Fontserè, 1937).

\section{Some study cases}

Let us now see some cases to show how the study of the preserved manuscript materials allows a new insight on different topics of interest in physical earth sciences. Three cases, covering pluviometric studies, macroseismic studies and instrumental seismology will be revisited in the following paragraphs.

\subsection{Pluviometry}

Pluviometry is a good example to show the importance of manuscript data. As has been stated, collection of rainfall data in Catalonia in the period 1894-1939 was done by several institutions. Additionally, there were several large observatories, most of them managed by religious institutions, that acted almost independently.

Table I shows schematically the evolution of the pluviometric networks in Catalonia. As three of the four stated institutions were of private origin, they had not always enough money to afford the publication of the collected data. Nowadays, there are important gaps in the published rainfall data. A second problem is that existing publications deal mainly with monthly data, not with daily rainfall.

In 1930, the Catalan Meteorological Survey, already aware of such problems, made a serious effort to fill this gap and recovered and compiled all the available rainfall data up to that time (Febrer, 1930). The results were impressive, but again only monthly data were used. Nevertheless, it is interesting to note that the pluviometric charts elaborated in 1930 differ in some aspects from the current ones (see fig. 1). This may just be due to the uneven coverage or to the applied system to plot the isohyetal lines, but it is worth taking some time to analyse the problem because no clear solution has been given for it up to now.

Instead, preserved manuscript archives, among them that recently recovered from the SMC (Batlló, 2003), preserve a lot of daily data. These data are of high interest for further studies: rainfall frequency, maximum daily precipitation, etc., may be analysed for a period covering a whole century.

\subsection{Macroseismic studies}

Since Fontserè was in charge of the seismological section of the Fabra Observatory in 1913, he took a special care to collect macroseismic data from earthquakes felt in Catalonia. He organized the meteorological observers of the Astronomical Society of Barcelona as the «Network of seismological observers of the Ibero-Pyrenean region». This was a good idea because in this way he gained a dense, motivated and quite well trained network of macroseis- 
Table I. Organization of meteorological observations and data sources in Catalonia.

- First network: Barcelona Experimental Farm (1894-1901)

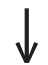

- Pluviometric Network of Catalonia (R. Patxot) (1901-1911)

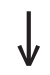

- Astronomical Society of Barcelona (1911-1921)

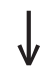

- Meteorological Survey of Catalonia (1921-1939)
Other observatories:

Observatori Català

Sant Julià de Vilatorta

Ebre Observatory

Fabra Observatory

Sabadell

Castell de Riudabella

Mataró

Montserrat, etc. a)

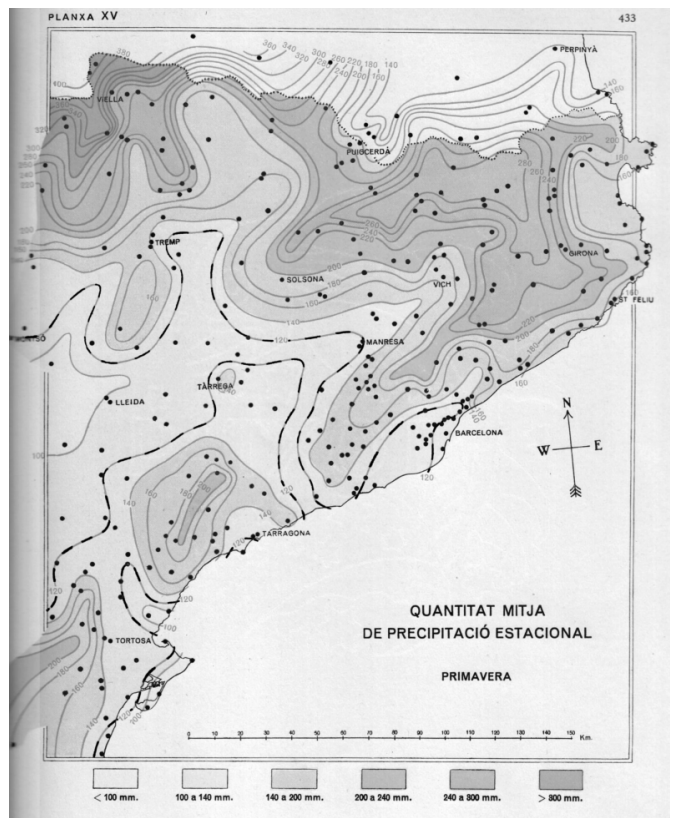

b)

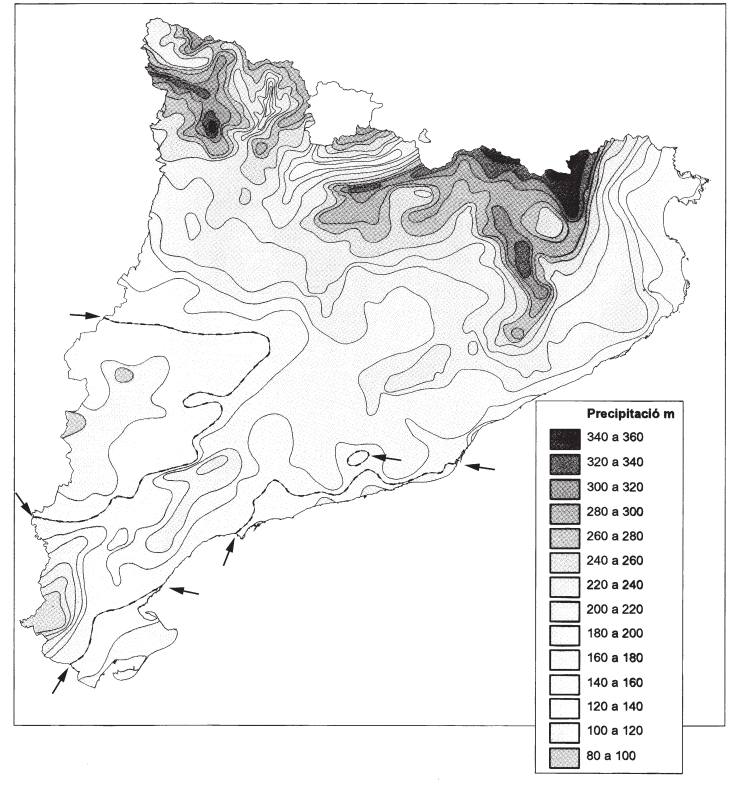

Fig. 1a,b. a) Pluviometric chart of Catalonia corresponding to spring months (March, April and May) as published in Febrer (1930). b) Current pluviometric chart for the same period. Note the clear differences in the $1201 / \mathrm{m} 2$ isohyetal lines beween both maps (in the second map the isohyetal line corresponding to $1201 / \mathrm{m} 2$ is marked with arrows.

mic observers. Each time an earthquake was felt the observers filled in macroseismic questionnaires, circulated them among neighbourhoods and sent them to the Fabra observatory, where they were collected and analysed. Initially, the observational results were published as a macroseismic bulletin but, lacking regular funds, publication soon stopped. In any case, all 


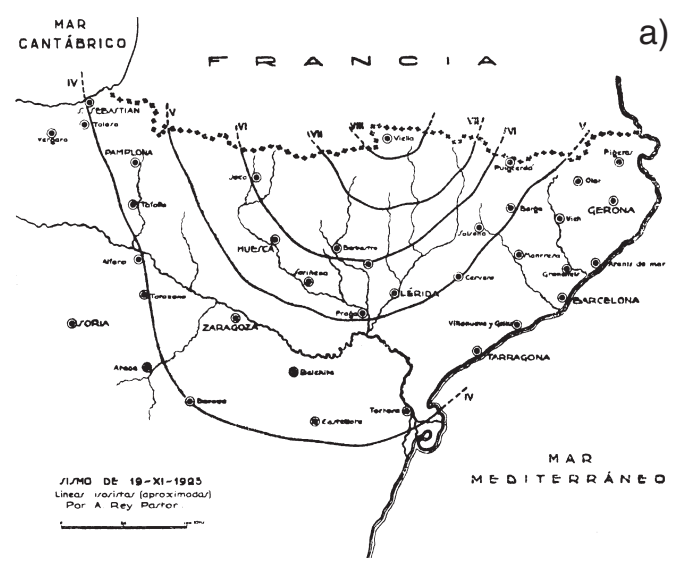

b)

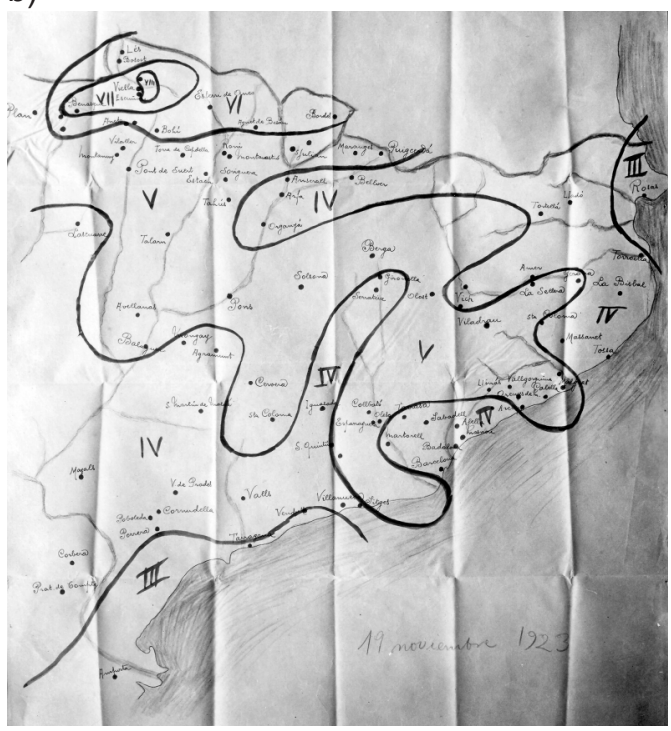

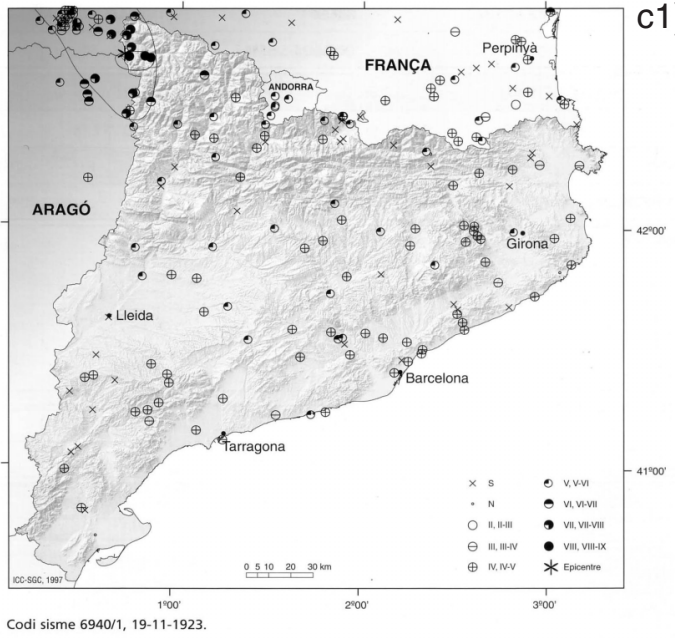

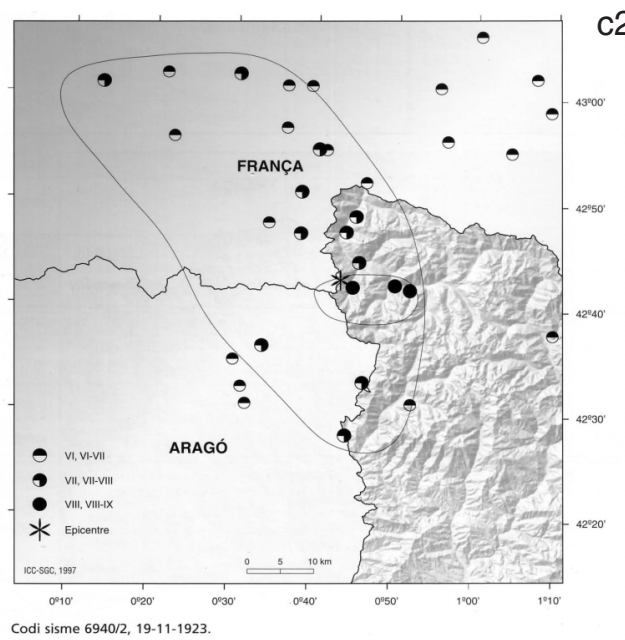

c2)

Fig. 2a-c. a) Macroseismic intensity map corresponding to the 19 November 1923 earthquake, in the Central Pyrenees, as published by Rey Pastor (from Galbis, 1932). b) Intensity map for the same earthquake drawn by Fontserè and preserved at the Fabra observatory archive. c1,2) Map for the same earthquake as published in Susagna and Goula (1999).

the collected information, with the original sheets, has been preserved in the observatory archives constituting a wonderful collection for the study of macroseismicity in Catalonia. Recently, all this information has been reelaborated and a new Atlas of Seismicity of Catalonia published (Susagna and Goula, 1999). The macroseismic data for this Atlas are backed by more than 4700 intensity data points, revised from the original sources, and allows isoseismal maps of 114 earthquakes to be plotted. Also, all these materials allow us to perform comparative studies on how the macroseismic data were acquired and maps drawn. As an example, 
fig. 2 shows three different maps for the same earthquake, the 19 November 1923 earthquake in the central Pyrenees (Susagna et al., 1994). The left figure shows the map drawn by ReyPastor (1927), director of the Toledo Central Observatory. Bottom left figure shows a manuscript map drawn by Fontserè with the data available to him through his «observers' network» and preserved at the Fabra archive. The right part shows the new map published in the new Atlas. As can be seen, Fontserè's map is really amazing. Probably this is the reason he never published it. It is clear that, in opposition with Rey-Pastor, he was trying not to smooth the information. These maps show how different interpretation can be depending on the author and deepens our understanding on the meaning of macroseismic maps.

\subsection{Seismic instrument location and characteristics}

Manuscript documents may also improve our knowledge of forgotten seismic stations. An example is the existence of seismic instruments in Madrid as early as 1887 and continued up to 1935 .

Although Madrid is the capital of Spain and the main office of the Spanish seismological survey has been there for so many years, the existence of a seismic station in Madrid has been always ignored. An early publication (Merino, 1905) alerted us to the possible existence of a seismic microphone in the Madrid astronomical Observatory. Recently, one of the documents preserved at the SMC archive (Batlló, 2003: sig. SMC-500-V/23) has been identified as a notebook containing the daily observations performed with this instrument between 1887 and 1889. It is clear that this finding has been a lucky coincidence, but shows how documents are found in unexpected places and it points to the necessity to be always aware. Continuing with the Madrid seismic station, and just showing the facts, news contained in the daily press gave us some information on the recording of the 1909 Benavente earthquake the occurred in Portugal. However, it is not clear which instrument was used at that time. Another letter pre- served again in the SMC archive informs us that a Bosch-Omori seismograph was installed in Madrid in 1910. This seismograph was in charge of the central meteorological office and it was in use probably until 1919. Finally, at the beginning of the thirties, the official telegrams of the Madrid seismic station were found in the notebooks of the Toledo and Fabra observatories. Also, some readings were published in the ISS volumes for those years but amazingly no official reference for this station exists. To increase our surprise, it should be noted that this coincided in time with the publication of the largest seismic catalogue of Spain (Galbis, $1932 ; 1940)$. Galbis himself was for many years in charge of the central meteorological office and it is clear he knew about this instrument. However, he ignored it (in the same way he ignored the station of the Milne network installed at Riotinto, in the South-West Spain) in writing his catalogue. A probable reason (not confirmed) for this may be that these instruments were not managed by the seismological survey. Coming back to the Madrid station, even the exact location of the observatory was not clear. In the first years, instruments were installed at the Madrid Astronomical Observatory but following the available written information later they were later installed in the buildings of the Central Meteorological Office. The exact location of this second place was totally unknown; but an interview with a retired employee of the meteorological office (A. Aspiroz, personal communication) allowed that location. The old building is still existing, but it has been totally rebuilt to the extent to be almost unidentifiable. Figure 3 shows the building in its original form.

Another example, the last, of a forgotten seismic station is the continuity of the seismic recording at the Perpignan observatory, in the south of France. It is known that a Secchi seismograph was installed in Perpignan in the last years of the 19th century. But it is almost unknown that the first Wiechert seismograph installed in Paris in 1909 was later transferred to Perpignan (in 1911), even though all this information is clearly stated in the «Annales du Bureau Central Meteorologique de France» corresponding to these years. A letter of O. Mengel, the director of the Perpignan observatory to E. 
a)

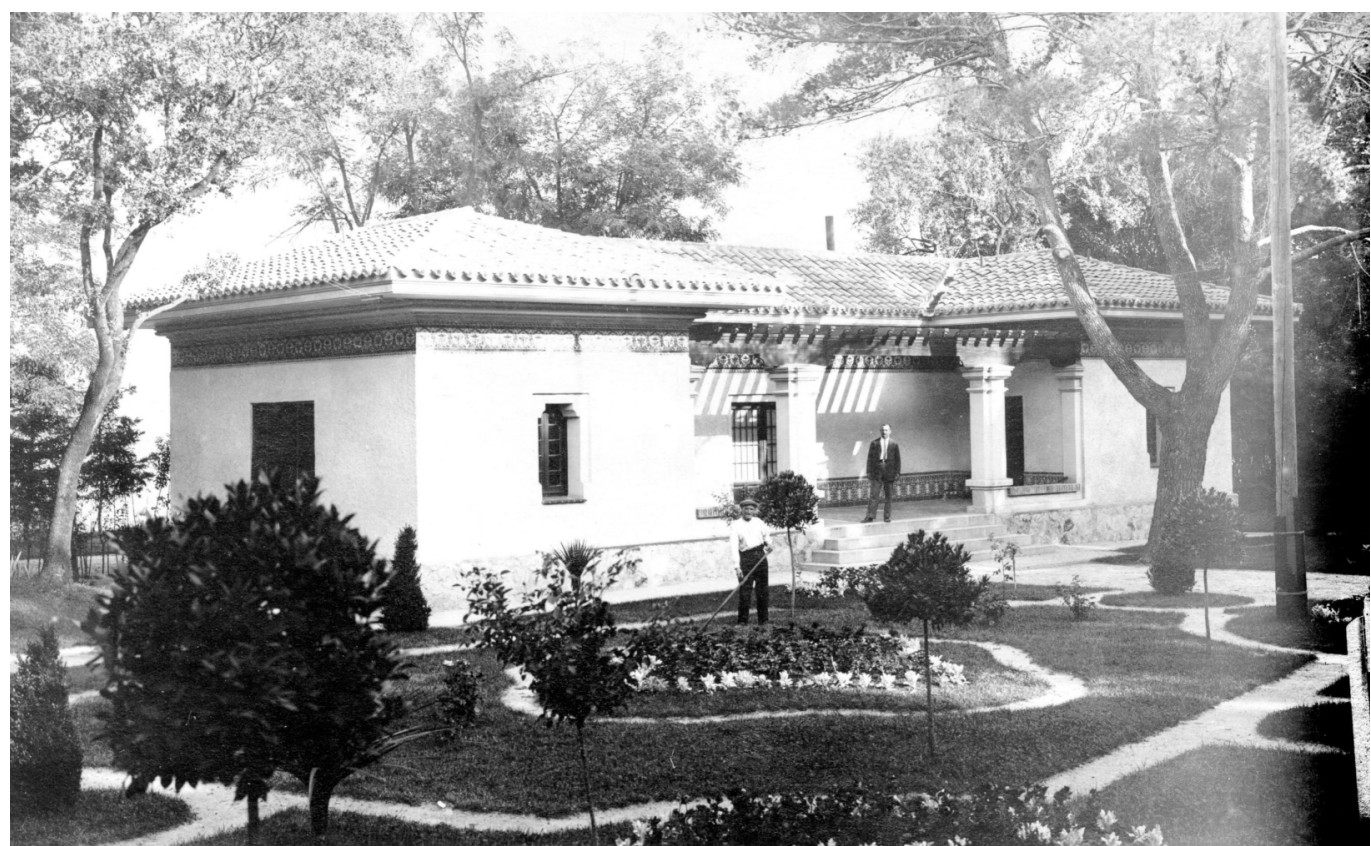

b)

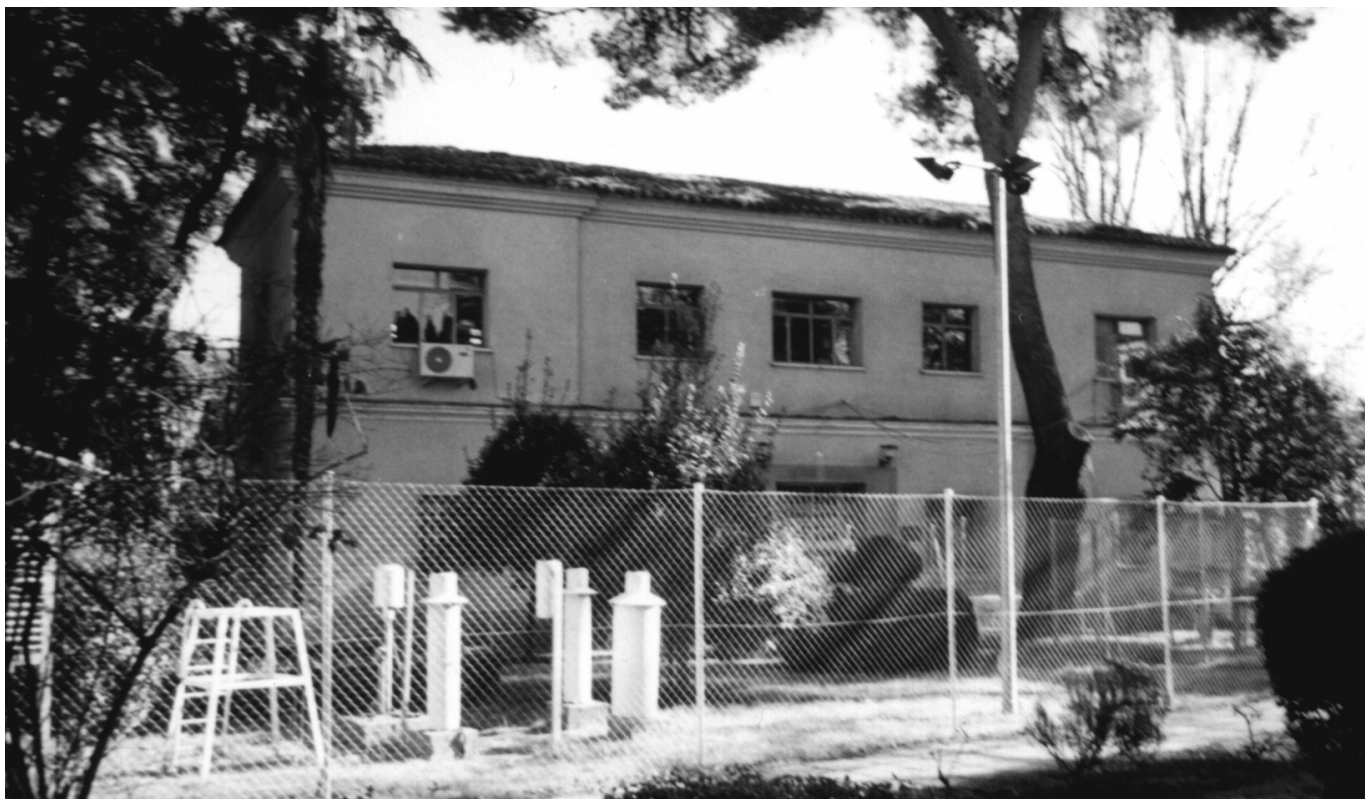

Fig. 3a,b. a) The Pavilion of the Madrid seismic station located at the Retiro Park built in the twenties (reproduced from the original photograph located at the archive of the Subdirección General de Geodesia y Geofísica, IGN, Madrid). b) The building was dramatically transformed in the forties (the porch disappeared and the building was raised with a second floor); but still exists. Note that the location of the pluviometers (to the right in the upper photograph) is almost unchanged. 
Fontserè, preserved in the SMC archive, states that, on the occasion of the 1923 Pyrenean earthquake of 19 November, both the Secchi and Wiechert instruments were still operative (even, in this case, Mengel says that the Wiechert instrument failed to record the earthquake). Again it is shown how manuscript references (instead of seismological printed references) improve our knowledge of seismic stations.

It is interesting to note that the two last cases concern seismic stations outside Catalonia, but important information has been found in the Catalan archives. This fact shows how important it can be to cross-check information located at different archives and from different sources.

\section{Conclusions}

As it has been shown, information sources for the physical earth sciences are multiple and scattered, especially in the cases where there is no centralised office in charge to manage and publish the data and complementary information.

In addition data validation often implies the knowledge of recording places, instruments, etc. This need for extra information demands the use of manuscript data.

Local and observatory archives are sources of new information. Cross-checking of these sources multiplies the available data and the obtained results. As an example, Batlló (this issue) shows how a combination of documents related to Ebre Observatory in Spain, and Casamicciola in Italy give enough information for the reconstruction of Grablovitz horizontal pendulums.

The information on the different earth science fields appears in mixed forms. Meteorological, seismological and astronomical data are found together, mainly because researchers used to work in all these fields at once. This fact suggests that a good optimized database in this field should include all these observational sciences.

A generalised cross-chek of information is necessary. If all the previously presented infor- mation is not readily available, a lot of strength is lost in the study of earth sciences. It is suggested that some kind of special coordination between earth sciences archives should be established. There are good examples to follow among the science archives as is the CASE group (2003) (Cooperation on Archives of Science in Europe) or, at a local level, the «Servei d'Arxius de Ciencia» (Roqué, 2003).

\section{Acknowledgements}

An important part of this work was elaborated by the author at Observatori de l'Ebre. Thanks are given to its librarian and also to the librarians of the Academia de Ciencies i d'Arts Barcelona.

\section{REFERENCES}

BARRIENDOS, M. (2005): Variabilidad climática y riesgos climáticos en perspectiva histórica. El caso de Catalunya en los siglos XVIII-XIX, Revista de Historia Moderna, 23, 11-34.

BATLló, J. (2002): Sismologia colonial: la introducció de la sismologia instrumental a les illes Filipines (18651901), in Actes de la Vl Trobada d'Història de la Ciència $i$ de la Tècnica, edited by J. BATLló et al. (Barcelona, Institut d'Estudis Catalans), pp. 215-224.

Batlló, J. (2003): Catàleg del fons històric del Servei Meteorològic de Catalunya, (available on line at http://www.icc.es/pdf/ca/common/cartoteca/fons_documental/cataleg_smc.pdf) (last accessed on february 2009).

Batlló, J. (2004): Josep Comas i Solà. Pioner de la sismologia a Catalunya, in Josep Comas i Solà. Astrònom $i$ divulgador, coordinated by A. RocA (Barcelona, Ajuntament de Barcelona), pp. 81-108.

CASE (COOPERATION ON ARCHIVES OF SCIENCE IN EuRope) (2003): Cooperation on Archives of Science in Europe, (available on line at http://www.bath.ac.uk/ncuacs/ case.htm) (last accessed on february 2009)

CIRERA, R. (1905): Notice sur l'Observatoire et sur quelques observations de l'éclipse du 30 Août 1905, (Mémoires de l'Observatoire de l'Ebre, no. 1, Barcelona, Gustavo Gili).

Febrer, J. (1930): Atlas pluviomètric de Catalunya, (Institució Patxot, Barcelona).

FONTSERÈ, E. (1937): Sobre les ciències d'observació a Catalunya, Nova Ibèria, 2.

GalBIS, J. (1932): Catálogo Sísmico de la zona comprendida entre los meridianos $5^{\circ}$ E. y $20^{\circ} \mathrm{W}$. de Greenwich y los paralelos $45^{\circ}$ y $25^{\circ} \mathrm{N}$, vol. I, (Instituto Geográfico, Catastral y de Estadística, Madrid).

Galbis, J. (1940): Catálogo Sísmico de la zona comprendida entre los meridianos $5^{\circ}$ E. y $20^{\circ} \mathrm{W}$. de Greenwich y 
los paralelos $45^{\circ}$ y $25^{\circ} \mathrm{N}$, vol. II, (Instituto Geográfico y Catastral, Madrid).

IgLeSIES, J. (1983): Eduard Fontserè. Relació de fets, (Fundació Salvador Vives Casajuana, Barcelona).

Maluquer, J. (1994): Rafael Patxot i Jubert. Mecenes $i$ científic, (Barcelona, Pòrtic).

Merino, M. (1905): Los terremotos experimentados en la Liguria y alta Italia, Suiza, y occidente y mediodía de Francia, Revista de los Progresos de las Ciencias Exactas, Físicas y Naturales, 22, 196-204.

PARDo, J. and A. MARTíneZ (2003): Annals de Medicina: expressió de la medicina catalana «noucentiste», in Actes de la VII Trobada d'Història de la Ciència i de la Técnica, edited by J. BATLLó et al. (Barcelona, Institut d'Estudis Catalans), pp. 333-336.

Patхот, R. (1908): Observacions de Sant Feliu de Guíxols. Resultats de 1896 (parcial) al 1905, (L'Avenç, Barcelona).

Patxot, R. (1912): Pluviometria Catalana, (Sant Feliu de Guíxols, Observatori Català).

Rey Pastor, A. (1927): Traits Sismiques de la Péninsule Ibérique, (Instituto Geográfico y Catastral, Madrid).

RocA, A. (1995): Eduard Fontserè i Riba: La Meteorologia
Professional, in Ciència i Tècnica als Pä̈sos Catalans: una aproximació biogràfica, edited by J. M. CAMARASA and A. ROCA, (Fundació Catalana per a la Recerca, Barcelona), pp. 859-908.

RocA, A. (2000): El canvi de segle (c. 1900): de la voluntad de renovació a l'estancament, in La Reial Acadèmia de ciències $i$ Arts de Barcelona als segles XVIII $i$ XIX: història, ciencia $i$ societat, edited by A. NIETO and A. RocA, (Institut d'Estudis Catalans, Barcelona), pp. 197-216

RoQué, X. (2003): El Servei d'Arxius de Ciència: creació i primeres realitzacions, in Actes de la VII Trobada d'Història de la Ciencia i de la Tècnica, edited by J. BATLló et al. (Institut d'Estudis Catalans, Barcelona), pp. 343-348.

SAdERRA MAsó, M. (1915): Historia del Observatorio de Manila, (E.C. McCullough \& Co., Inc., Manila).

Susagna, T., A. Roca, X. Goula and J. Batlló (1994): Analysis of macroseismic and instrumental data for the study of the November 19, 1923 earthquake in the Aran Valley (Central Pyrenees), Natural Hazards, 10, 7-17.

Susagna, T. and X. Goula (1999): Atles sísmic de Catalunya, (Institut Cartogràfic de Catalunya, Barcelona). 